\title{
Thom Brooks's Project of a Systematic Reading of Hegel's Philosophy of Right
}

\section{Paul Redding}

Thom Brooks's Hegel's Political Philosophy: A Systematic Reading of the Philosophy of Right presents a very clear and methodologically self-conscious series of discussions of key topics within Hegel's classic text. As one might expect for a 'systematic' reading, the main body of Brooks's text commences with an opening chapter on Hegel's system. Then follow seven chapters, the topics of which (property, punishment, morality, family, law, monarchy, war) are encountered sequentially as one reads through the Philosophy of Right. Brooks's central claim is that too often Hegel's theories or views on any of these topics are misunderstood because of a tendency to isolate the relevant passages from the encompassing structure of the Philosophy of Right itself, and, in turn, from Hegel's system of philosophy as a whole, with its logical underpinnings. Brooks is clearly right in holding that Hegel had intended the Philosophy of Right to be read against the background of 'the system' and the 'logic' articulating it — nobody doubts that - but there is a further substantive issue here. Should contemporary readers heed Hegel's advice? Brooks's answer is emphatically in the affirmative, and what results is a series of illuminating discussions in which he makes a case for his own interpretations on the basis of systematic considerations, presented against a range of alternatives taken from the contemporary secondary literature, which is amply covered, often in the extensive endnotes to the book.

Beyond that of showing that the Philosophy of Right is better read in a systematic way, however, lies a further, and more ambitious aim. Noting the existence of a contemporary debates over the question of Hegel's 'metaphysics', Brooks intends his work as an intervention into the current situation of Hegel interpretation that is meant to 'sublate' the warring 'metaphysical' and 'non-metaphysical' stances 'in favour of a systematic reading which occupies their middle ground' (Brooks 2007: 10-11). I will return to this broader aim at the conclusion of this essay, but for the moment will simply note that, as set out in the 'Introduction', Brooks's treatment of these issues is not as clear as his treatment of particular topics within the body of the text, and is, in places, confusing. For example, Brooks runs together the two very different debates at issue: that between the 'systematic' and 'non-systematic' approaches to Hegel's political philosophy, and that between the 'metaphysical' and 'non-metaphysical' interpretations of Hegel's broader philosophical project: 'the non-metaphysical approach is best understood as a non-systematic reading of Hegel's work' (Brooks 2007: 3), and 'those who generally adhere to a systematic reading also adhere to a metaphysical reading; those who generally adhere to a non-systematic reading also adhere to a non-metaphysical reading' (Brooks 2007: 6). In particular, one might find it puzzling as to why Robert Pippin or Terry Pinkard - 
surely exemplary 'non-metaphysical' readers of Hegel — should be thought of as nonsystematic readers. For example, roughly one third of Pippin's influential Hegel's Idealism is devoted to Hegel's logic (Pippin 1989: 175-260), which certainly looks like it is taking Hegel's systematic claims seriously. Moreover, these readings are based on the idea of Hegel as a developer of central features of Kant's philosophy, and surely Kant, if anyone, aspired to systematicity. And typically the complaints of post-Kantians such as Hegel were that Kant had not lived up to his systematic aspirations: philosophy had to be made more systematic.

I think it is clear that Brooks's natural opponent here is a non-systematic reader like Allen Wood, not the very different 'non-metaphysical' reader, like Pinkard or Pippin, and blurring this distinction does not help define his aim. Further than this, running together these debates in this sort of way seems to cut across Brooks's own aim to stand aloof from the metaphysical/non-metaphysical debate, and indeed, to 'sublate' these positions, from the 'systematic' point of view. I will return to these issues, but first want to look at some of the particular interpretations of Hegel's doctrines found in chapters 2 to 8 -interpretations based on a 'systematic' approach.

The idea of a systematic interpretation seems to be applied in different although not incommensurable ways throughout the book. For example, in discussion of Hegel's theories of property and punishment in chapters 2 and 3, Brooks appeals mostly to a systematicity that is internal to the Philosophy of Right itself. For example, he notes that many writers on Hegel's theory of property rely almost exclusively on what Hegel says about property relations in 'Part One' of the work, 'Abstract Right'. But, as he points out, surely Hegel's theory of property cannot be understood in isolation from his theory of law, and there is no systematic place for 'law' within Abstract Right (Brooks 2007: 37). (This seems right. Presumably an initial consideration of an agent's possession of a 'right' requires less complex logical categories than those required to grasp the idea of law-like relations, in the way that the idea of an object's property, at least initially, seems understandable without reference to abstract laws governing the behaviour of the object.) So it is a mistake to look for a 'complete' theory of property, or a theory of property 'per se', in Section One. Further, different considerations come into play, when one looks to Hegel's discussion of property in later parts of the book - in particular, in the context of 'Civil Society', within Part 2.

The same strategy is employed in relation to Hegel's theory of punishment in Chapter 3. Hegel is commonly taken as having a retributivist theory of punishment, again on the basis of his treatment of punishment in Part 1, Abstract Right (Section 3 devoted to 'Wrong [Das Unrecht]'. But Hegel's retributivism, Brooks argues, is a minimal one, amounting to no more than the dictum that only deserving persons can be punished. When one places punishment in contexts that emerge beyond Part One, the significance of further non-retributive functions that punishment serves in Hegel's philosophy emerge. Again, it is the connection between punishment and law that is left obscure in a reading restricted to Hegel's discussion of punishment in Part One. 


\section{Paul Redding}

It is when using this form of appeal to 'systematicity' that I found Brooks's arguments most persuasive and illuminating, but clearly such a strategy of tracing topics thematic raised in earlier sections through more complex contexts that appear in later sections of the work is going to work best for early chapters. Any systematic treatment of topics raised in later chapters will need to adopt some other strategy. Effectively, this means that Brooks has to appeal more substantially to Hegel's 'logic' in the later than he does in the earlier chapters, and, to my mind, this is where problems for the idea of a 'systematic' reading first emerge. The basic problem is that the interpreter will need to presuppose quite substantive assumptions about the nature of Hegel's logic itself, and thereby risk their own interpretations of particular topics being held hostage to those assumptions. Hegel's Science of Logic is, of course, a huge and very puzzling work. The ten or so pages that Brooks dedicates to this part of Hegel's philosophy in Chapter One, 'System', cannot be expected to provide anything other than a sketch. I take it that Brooks hopes that his sketch can be kept to a few general uncontroversial but nevertheless explanatory aspects of Hegel's logical project, but with Hegel this seems to me to be doubtful.

In particular, it is unlikely that issues here are going to swing free from the sort of substantive debates about Hegel's basic intentions that make up the 'metaphysical-nonmetaphysical' dispute. Contrast, for example, the general picture of Hegel's logic that emerges from the interpretations of readers like Stephen Houlgate on the one hand, and Robert Brandom on the other. But, more radically still, consider those who are sceptical about the very coherence of Hegel's whole project of 'logic', an attitude that may motivate a non-systematic reading of Hegel. It is likely that many contemporary philosophers, including some with an interest in Hegel, will find Hegel's logic incoherent. This was Russell's diagnosis a hundred years ago, when he claimed that Hegel's logic was based on a fundamental logical error that he had inherited from Leibniz — an error regarding logical form that led to the consequence of thinking all truths as ultimately truths about the one subject — 'the Absolute'. On this reading of Hegel's logic, it is not about anything at all, and will be seen as just a confusing imposition on what otherwise may be an interesting political philosophy. Again, I will return to this topic later, but for the moment I want to concentrate on passages where I think particular and contestable assumptions about Hegel's logic appear in the context of Brooks's analyses.

As mentioned, in his discussion of property and punishment Brooks's appeals to Hegel's treatment of law, and while I found the chapter devoted to this topic, chapter 6, to be extremely helpful and illuminating, one might nevertheless see there the way in which contestable assumptions about the nature of Hegel's logic can come into play. Brooks argues that Hegel should be seen as an atypical proponent of natural law theory. Like the natural lawyers, he distinguishes 'true' law from historically given particular laws; grounds true law in the criterion of justice; and holds true law to be universal or 'eternal'. But in contrast to standard natural law theory, he regards the norms against which historically given laws are to be assessed as internal to those laws. On such an 'internalist' 
version of natural law, 'we do not begin our assessment of law with a normative standard in hand; we begin with the law as it is before us': justice is not 'something we apply externally to the law, but a normative standard that immanently develops with the law itself (Brooks 2007: 87). Brooks here follows Robert Stern's idea of an 'internal' notion of rationality' which has it that natural law emerges in the process of 'the resolution of inconsistencies and anomalies' within existing laws (Brooks 2007: 88).

This gives us an illuminating way of bringing logical concerns to bear on his conception of jurisprudence, and looks promising indeed, although one might pause at Brooks's attribution of an eternalist conception of true law to Hegel. On Brooks's account, an important part of this internally rational process will be the codification of those 'unwritten' laws that are immanent in the normative practices of a community. It is in this way that the laws become self-conscious rather than mere habits and conventions, because such codification opens up the question of the consistency among those laws. This seems right. There is a tight link in Hegel between the capacity for selfconsciousness and the capacity to grasp some ('conscious') content by grasping its place within the logical space of antecedents and consequents. But Brooks realises that issues of formal consistency alone are not themselves sufficient here, and goes on to show the importance for Hegel of the role played by the institutions within which such laws obtain a grip on the social life of the community.

While this seems to capture well the way rational, institutional and historical considerations come together in Hegel, I still wonder if the conception of logic that is implicit in Brooks's picture is actual consistent with logical processes as Hegel conceives them. Brooks notes that for Hegel the law is a 'seamless web', and he treats the idea of progress here as via the resolution of 'inconsistencies and anomalies' in which we 'fill gaps' in this web (Brooks 2007: 89). The picture suggested is one in which the perfectly rational 'eternal' shape of law implicit in actual laws opposes the potentially irrationality of its application by us finite temporal beings, 'collisions [Killisionen]' thus arising 'in the imperfect application of laws in some instances' (Brooks 2007: 93). Brooks is surely right in the claim that such collisions are important for Hegel, but his sketch seems to suggest too-weak a picture to capture the processes of 'negation' meant to be driving such 'collisions' in Hegel's dialectic: rather than a clash between the rational law and its imperfect applications, 'negation' for Hegel, I suggest, is to be thought as immanent within 'the law' itself- the 'true' law, not just its imperfect historical manifestations. In contrast, the 'seamless web' conception of conceptual coherence sounds much more like that found in Kant: a type of formal coherence possessed, for example, by the 'transcendental unity of apperception', or at work in the practical context of the categorical imperative. But Hegel is resolutely critical of this dimension of Kant's thinking, identifying the type of rationally articulated within such a web with 'the understanding' rather than 'reason'.

The question of how to read the logic also emerges pointedly in Brooks's discussion of Hegel's advocacy of a monarchical form of government in Chapter 7. Again, 


\section{Paul Redding}

Brooks says many illuminating things here, and is surely right in insisting that Hegel's advocacy of a monarchical form of government must be taken seriously as a necessary outcome of Hegel's system rather than just some idiosyncratic 'add on' that one might discard in the attempt to make his political theory more appetising. And he is right, I suggest, in wanting to ground Hegel's approach to the monarchy in the peculiarities of his logical categories - centrally, in the trichotomous structure of 'universality', 'particularity', and 'individuality' (Brooks 2007: 99). However, one can challenge the application he gives to these categorical structures, and the lessons he draws from them. When applied in a different way they can be seen to support the very reading that Brooks contests in this chapter, rather than his own. Here I'm not particularly concerned with which interpretation of these categories is correct; the point is simply that appealing to such logical considerations will always presuppose complex interpretative questions about Hegel's logic itself, questions that raise issues beyond the type of sketch that could be given in Chapter 1.

Brooks applies Hegel's trichotomous structure by saying that, in the monarchical state, 'the Idea takes shape as a particular individual with universal powers: the monarch. The monarch is thus thought to unify universality, particularity, and individuality' (Brooks 2007: 99). But why, we might ask, not describe the monarch as simply 'an individual with universal powers' or perhaps a 'particular person with universal powers'? Why are there three categories involved here, and not just two? At first pass, this type of formulation looks like the type of artificial category-twisting that the sceptics find redolent within Hegel's logical thought -an attempt to twist the world to the procrustean bed of his idiosyncratic logic.

There is, I believe, a reply in Hegel's defence here, but to appreciate Hegel's point one needs to be aware of the importance of a distinction that is not obviously reflected in the English usage of these terms, nor standardly in Anglophone philosophy, where terms like 'singular', 'particular' and 'individual' seem pretty much interchangeable. Both Kant and Hegel distinguish between the categories of 'singularity [Einzelnheit]' and 'particularity [Besonderheit], and the distinction appears to go back to Aristotle's distinction between singular and particular judgments, a singular judgment using a singular term as subject (e.g., 'Socrates is mortal') and a particular judgment using some natural kind term within the subject phrase (e.g., 'This man is mortal'). This distinction was associated with an important logical problem facing Aristotelians: the problem that singular judgments as such could not have a proper role within syllogistic inferences (and thereby within science) because the component terms of syllogisms are meant to be able to play both subject and predicate roles, and proper names are restricted to subject position. Various ways around this problem had emerged: singular terms could be treated as universals (a move repeated by Quine in the $20^{\text {th }} \mathrm{C}$ ), or judgments about individuals could be put in the form of 'particular judgments', sentences like 'Socrates is mortal' being replaced by particular ones like 'this man is mortal' where 'this man' was taken to refer to Socrates. 
These issues had been made relevant for the idealist tradition by Leibniz who had treated singular and particular judgments as logically equivalent, a move that Kant had reacted against by treating the category of 'Einzelnheit' as pertaining to the content of empirical intuitions, which he distinguished from concepts as distinct forms of representation. Hegel had further complicated things: first, by not accepting Kant's concept-intuition distinction as fundamental; next, by insisting on the category of 'individuality' as signifying a type of organic internally-articulated and self-sufficient individual in which the dichotomous distinction between 'particularity' and 'universality' was somehow resolved; and then in construing 'singularity' as something like the immediate, undifferentiated form that was sublated into 'individuality'.

Whatever way this complicated story may turn out here, the distinction between singularity and particularity is obviously crucial for understanding Hegel's account of the monarch. 'The monarch' Brooks quotes Hegel, 'is essentially determined as this individual [dieses Individuum] ... and this individual is definite [bestimmt in an immediate and natural way, i.e., by his natural birth' (Hegel 1991: \280). Significantly, the immediately prior sentence in the Philosophy of Right reads, 'Seen in abstraction, this ultimate self of the will of the state is simple and therefore an immediate singularity [unmittelbare Einzelnheit], so that the determination of naturalness is inherent in its very concept' (ibid.). ${ }^{1}$ A number of considerations are relevant here. First, as one learns from the opening chapters of the Phenomenology of Spirit, for Hegel demonstratives which pick out things in their 'singularity' only do so in that they can be connected to a concept: 'this' is always a 'this such' — 'this book', 'this tree' or, indeed, 'this monarch'. In the terms under consideration here, any singular is also graspable as a particular. Hence, in a sense, Hegel agrees with Leibniz in his willingness to identify the 'singular' and 'particular' presentations of some entity. However, Hegel also agrees with Kant's diagnosis of the consequences of making this identification - the genesis of contradictions - but he differs from Kant in the attitude taken to such contradictions. Crudely, Kant instructs thinking to avoid falling into these contradictions in the first place (that is, avoid metaphysics) while Hegel, responding to the unavoidability of such falling, tells us that we had better learn how to deal with them.

Applying this to the question of the monarch: the ability to identify singularity and particularity here does not do away with this distinction: neither does it annul singularity as a determination (although Hegel is often accused of this, by Kierkegaard, for example), nor reduce it to particularity. This monarch is, of course, a monarch-an instance of the kind monarch. But Hegel insists that in this case that instance must primarily be understood in its singular determination — this natural person bere- who, in this sense escapes being total determined by the concept. (This is somewhat equivalent to the way Kant thinks of the determinate content of perceptual judgments as dependent on something nonconceptual, something given in 'intuition'.) Insisting on the singularity of the monarch over considerations of determination by the concept is in contrast to the way in which we are to think of other individuals involved in the political process, the ministers of the monarch's cabinet, for example. A minister is to be thought of as a 'particular', that is, in 


\section{Paul Redding}

terms of instantiations of their 'concept' - the normative identity this person has as bearer of this social role. The minister, for example, is held accountable in the process by the legislature because he is meant to embody certain characteristics that fit him to that role. His requisite characteristics are, we might say, defined by the role he has to play in the process. But the monarch, thinks Hegel, is not regarded in this way. Paradoxically, to be thought of as an instance of this concept, the concept 'monarch', is to be thought of in such a way that is freed from ultimate determination of any concept — to be determined 'in an immediate and natural way'.

Hegel's claim here is certainly odd for a 'rationalist' and seems to cut against the grain of our own rational intuitions. We want to ask about the occupants of certain elevated social statuses the question 'why that person?', and we want to be given some list of the qualities that justify that status. But with the monarch, on Hegel's account, we are properly given an answer that looks akin to, say, possession of a certain height or eyecolour — that person is rightly monarch because they are simply the eldest offspring of another person who attained that status in just the same way. This is just the type of 'irrationality' about hereditary monarchy that makes typical republicans fume. Why should Hegel think it an answer at all, let alone the best answer?

I certainly don't want to attempt an answer here, but only want to note that it is a question that goes to the heart of Hegel's logic. The seeming irrationality of the answer to 'why this person is the monarch' is mirrored in a comment that Brooks quotes from John Findlay, "The functions of the Monarch in the State is simply to take the last decisions... The monarchical majesty resides, further, in the complete groundlessness of these last decisions' (Findlay 1958: 324, in Brooks 2007: 104). Brooks puzzles about such claims, focusing on Hegel's famous claim that 'the supreme office should be such that the particular character [die Besonderheit des Charakters] of its occupant is of no significance' and that with respect to capacity of the monarch for 'ultimate decision', those qualities possessed by the monarch that 'belong to [the sphere of] particularity ... must not be allowed to affect the issue' (Hegel 1991: \$280A). Such claims that we must exclude considerations of the particular character of the monarch are, Brooks says, inconsistent with Hegel's overall view of the monarch' (Brooks 2007: 113). But I suggest that Brooks has it the wrong way round. Whatever we make of these doctrines, these sorts of claims are precisely the claims that are grounded in Hegel's logical theory, and in the privileged status that the monarch has as instantiating singularity, rather than particularity.

Again we are dragged into the dark recesses of Hegel's logic that generate his approach to negation and contradiction, regions which lead many to question the very coherence of Hegel's logical project. But it could be that there is something deep and important at work is these regions of Hegel's logic. Contra Russell's easy dismissal, we might even think of Hegel's confronting the issue of contradiction as having anticipated Russell's famous paradox, seen as generated by issues similar to the identification of 'singularity' and 'particularity' —in the case of Russell, expressed in terms of the consequences of identifying a member of a single-member set with the set itself. As with 
Kant and Leibniz before him, I suggest, there is something radically 'modern' at stake in this wrestling with the issues of singularity, an issue that is in turn bound up with that other distinctly 'modern' issue, that of 'subjectivity', given that our own immediate selfapprehension seems to instantiate just this type of immediate apprehension.

Finally, I want to return to those more general methodological issues raised by Brooks in his Introduction. As I suggested earlier, there are confusing aspects of the way Brooks sets his book in relation to contemporary debates. The subtitle of his book clearly qualifies it as an approach which primarily contrasts with a non-systematic reading that would be based on the assumption that Hegel's arguments 'can be accurately reconstructed within the Philosophy of Right without substantive recourse to other parts of his system, and most especially without reliance on Hegel's logic that underpins his system' (Brooks 2007: 5). Brooks gives a long list of non-systematic readings, among which he includes Allen Wood's Hegel's Ethical Thought, which, as he notes in the 'Conclusion', has been 'a principal target throughout' (Brooks 2007: 129).

Anyone familiar with the 'Introduction' to Hegel's Ethical Thought will be aware that for Wood Hegel's logic is dead. That is, Wood instantiates just that attitude to the vacuity of Hegel's logic mentioned above as a common position among contemporary philosophers. But for Wood, the death of Hegel's speculative logic does not imply the death of Hegel's thought. 'The Hegel who still lives and speaks to us is not a speculative logician and idealist metaphysician but a philosophical historian, a political and social theorist, a philosopher of our ethical concerns and our cultural identity crises' (Wood 1990: 5-6). Thus for many of those wanting to retrieve something valuable from Hegel's philosophy, Wood's position will have a definite attraction.

Brooks does not deny that there might be a certain utility in the non-systematic approach, but he is critical of the idea that this reveals the real Hegel, and here invokes a worry that is voiced by Frederick Beiser that with such an approach we 'learn from Hegel ... only what we have read into him' (Beiser 2005: 4, in Brooks 2007: 10). With this the suggestion is clearly that by, adopting the systematic reading we will learn something from Hegel that eludes his non-systematic readers, but the image chosen by Brooks for his front cover might have already signalled to the reader something of the disappointing message to be found at the conclusion of the book. The cover of Hegel's Political Philosophy shows Tynemouth Castle, an edifice that, we are told 'shares much in common' with Hegel's philosophy. When the question of 'what is living' in Hegel's philosophy is raised, we might then not be surprised by Brooks's 'sympathy' with an answer given by Michael Rosen: 'nothing' (Rosen 1982:179 and in Brooks 2007: 131). From the cover image, it certainly looks like no-one lives, nor could live, in Tynemouth Castle, and so while Wood has been a principle target of Brooks reading, one might suspect that they actually agree about a considerable amount. In particular, they seem to agree that if one takes Hegel's philosophy in the way that Hegel had meant it, then it is going to turn out to be a ruin. That is precisely why Wood avoided such a reading. Brooks takes the other alternative to show to us the ruin in all its ruinous splendour. I actually share Brooks's enthusiasm 


\section{Paul Redding}

for systematic readings of Hegel, but it is only because I am not as sceptical of the value of Hegel's logic as Wood or Rosen, or at least, maintain the hope that one need not be so. Were I to share this (surely understandable) scepticism, I would favour Wood's approach over that of Brooks for the reasons he gives.

In sum, the value of a systematic reading of Hegel cannot, I believe, be isolated from the question of the value of Hegel's system, and the value of that cannot be isolated from the question of the coherence of Hegel's logic. There is little hope of a helpful stance here that stands aloof from the hurly-burley of contemporary approaches to making sense of Hegel's philosophy as a whole. For this reason, I do not see Brooks's approach as capable of achieving a 'sublation' of these warring positions. This, however, does not detract from its more basic aim of shedding light on various aspects of Hegel's political philosophy from a systematic point of view.

\section{Paul Redding \\ University of Sydney \\ paul.redding@sydney.edu.au}

\section{Notes}

${ }^{1}$ The translation is emended. Nisbet renders 'unmittelbare Einzelnheit' here as 'immediate Individuality'. While singularity may be, in some sense, individuality in its immediate form, the more literal translation underlines the point more directly that it is the category of singularity, not individuality, that is at issue here.

\section{Bibliography}

Beiser, Frederick (2005), Hegel. London: Routledge.

Brooks, T. (2007), Hegel's Political Philosophy: A Systematic Reading of the Philosophy of Right.

Edinburgh: Edinburgh University Press.

Findlay, J. N. (1958), Hegel: A Re-examination. London: George Allen \& Unwin.

Hegel, G. W. F. (1991), Elements of the Philosophy of Right, ed. Allen W. Wood, trans. H. B.

Nisbet. Cambridge: Cambridge University Press.

Pippin, Robert B. (1989), Hegel's Idealism: The Satisfactions of Self-Consciousness. Cambridge:

Cambridge University Press.

Rosen, Michael (1982), Hegel's Dialectic and its Criticism. Cambridge: Cambridge University Press.

Wood, Allen W. (1990), Hegel's Ethical Thought. Cambridge: Cambridge University Press. 